J. Product. \& Dev., 14(3): 683- 700 (2009)

\title{
EFFECT OF GROWING MEDIA AND CHEMICAL FERTILIZATION ON GROWTH AND CHEMICAL COMPOSITION OF Dracaena marginata "BICOLOR"
}

\author{
A. A. EL Sayed*, A.S. El-Leithy* and S. M. A. O. Heider* \\ *Ornamental Horticulture Department, Faculty of Agriculture, Cairo \\ University, Giza, Egypt.
}

\begin{abstract}
This study was carried out at Ornamental Horticulture Department,Faculty of Agriculture, Cairo University during two seasons; 2007 and 2008 aiming to study the effect of different soil media (peatmoss or peatmoss + sand (1:1 by volume), NPK (19:19:19) fertilization at 0, 1, 2, 3 and $4 \mathrm{~g} /$ plant and spraying with trace elements (Fe, Mn and $\mathrm{Zn})$ at 50 and 100 ppm on growth and chemical composition of Dracaena marginata 'Bicolor'. The results showed that growing plants in peatmoss medium gave the highest values of plant height, number of leaves/ plant, fresh and dry weights of leaves/ plant, total carbohydrates, $\mathrm{N}, \mathrm{K}, \mathrm{Fe}, \mathrm{Mn}$ and $\mathrm{Zn}$ percent in leaves. Whereas peat + sand medium gave the highest values of stem diameter, leaf area and $P$ contents in leaves in both two seasons.

NPK at 1 and $2 \mathrm{~g}$ and NPK fertilizers plus trace elements increased plant height, stem diameter, number of leaves/plant, leaf area, fresh and dry weights of leaves/ plant compared with control in the first and second seasons. Also, all chemical fertilization treatments increased total carbohydrates, $N, P, K, F e, M n$ and $\mathrm{Zn}$ percent in leaves as compared with control plants in the first and second seasons.

Using peatmoss or peatmoss + sand medium combined with NPK at $1 \mathrm{~g} /$ plant alone or NPK at $1 \mathrm{~g}$ plus trace elements gave the highest values of most characters.
\end{abstract}

Key words: Dracaena marginata, soil media, NPK fertilization and trace elements.

\section{INTRODUCTION}

Dracaena is a genus of about 40 species of trees and succulent shrubs classified in the family Ruscaceae in the APG II system, or, according to some treatments, separated (sometimes with Cordyline) into a family of their own, 
Dracaenaceae or in the Agavaceae. The majority of the species are native in Africa, with a few in southern Asia and one in tropical Central America.

Dracaenas are propagated commercially by vegetative methods. Dracaena marginata and its cultivars are propagated from cuttings or, in a few instances, air layers are used on relatively large stems. Most small dracaenas are started from terminal cuttings with foliage to the base. Very large cuttings and layers generally have exposed stems at the base. Plants can be propagated from cane sections, but are rarely done so because of the undesirable branching angle of shoots from the upper portion of cane. Most propagation material used by Florida growers comes from the Caribbean Basin and Central America, although a few nurseries in south Florida maintain stock plants of D. marginata in full sun. Cuttings placed in small pots are usually plunged to the bottom to insure support. Cuttings and layers used in larger containers are set slightly above the base to provide a better environment for root development.

It is a popular houseplant that needs little attention, with several cultivars available with the leaves variegated with red or pale yellow. It requires a minimum temperature of $15^{\circ} \mathrm{C}\left(59^{\circ} \mathrm{F}\right)$, and is more tolerant than most plants of dry soil and irregular watering, though liable to root decay in permanently wet soil. Because it requires minimal care it is very popular in offices where the constant heat and light suits their growing requirements.

It has been widely confused with other species of Dracaena, and many or most of the plants in cultivation under this name may actually be D. cincta or D. concinna (Huxley, 1992).

Many factors affecting growth of many foliage plants, such as growing media; Wazir et al. (2003) on Dracaena deremensis; Wazir et al. (2004) on Schefflera actinophylla; El-Khateeb et al. (2006) on Ficus alii; Papafotiou et al.(2008) on Codiaeum variegatum and Salvador (2008) on Polypodium aureum.

Also, NPK fertilization affecting growth of many foliage plants; Poole and $\mathrm{Li}$ and Zhang (2002) on Anthurium andraeanum; Wazir et al., (2004)on Schefflera actinophylla; Dorgham (2005) on Dieffenbachia and Philodendron erubescens; Jimenez and Lao (2005) on Dieffenbachia amoena; Segura et al. (2005) on Dieffenbachia maculata and Srinivasa (2006) on Anthurium andraeanum.

The effect of trace elements were studied by many authors; Said (1997) on croton plant and Dorgham (2005) on Dieffenbachia and Syngonium podophylum plants. 


\section{MATERIALS AND METHODS}

This study was carried out at Ornamental Horticulture Department, Faculty of Agriculture, Cairo University during two seasons 2007 and 2008 aiming to study the effect of NPK (19:19:19) fertilization, trace elements (Fe, Mn and $\mathrm{Zn}$ ) and growing media on growth and chemical composition of Dracaena marginata 'Bicolor'.

Dracaena marginata 'Bicolor' terminal rooted cuttings with $10-15 \mathrm{~cm}$ length were transplanted on January $25^{\text {th }} 2007$ and 2008 in $20 \mathrm{~cm}$ pots ( one plant/ pot) filled with different soil media ( peatmoss or peatmoss + sand (1:1 by volume) and after one month of transplanting the plants received the first application of fertilizers ( NPK at 1, 2, 3and $4 \mathrm{~g}$ / plant and NPK at $1 \mathrm{~g}+$ spraying trace elements $(\mathrm{Fe}+\mathrm{Mn}+\mathrm{Zn})$ at 50 and $100 \mathrm{ppm}$. The plants were located under the greenhouse condition and irrigation was done as the plants needed.

The plants fertilized monthly with NPK at the mentioned doses. Trace elements (Fe 6\% - Zn 12\% - Mn 10\%) were mixed and dissolved in a tap water at 50 and $100 \mathrm{ppm}$ and added as spraying monthly on the plant leaves.

The layout of the experiment was split plot design, which soil media represented as main plots, while chemical fertilization treatments represented as sub plots in three replicates, each replicate consisted of 4 plants.

The following data were recorded during the growth period for nine months. In the end of the experiment plant height $(\mathrm{cm})$, stem diameter $(\mathrm{cm})$, leaves number, leaf area $\left(\mathrm{cm}^{2}\right)$, fresh and dry weights of leaves , total carbohydrates, N, P, K, Fe, Mn and Zn percent in leaves were determined.

Total carbohydrates in dried leaves was determined according to Herbert et al. (1971) Nitrogen content was determined by the modified micro kieldahl method as described by Pregl (1945).

Phosphorus content was estimated as recommended by Troug and Meyer (1939).Potassium content was determined according to Piper (1950). Iron, manganese and zinc were determined by using flame emission spectrophotometer with a boiling air-acetylene burner (Isaac and Kerber, 1971).

Data recorded on vegetative growth, were statistically analyzed, and separation of means was performed using the Least Significant Difference (L.S.D.) test at the 5\% level, as described by (Snedecor and Cochran, 1980). 


\section{RESULTS AND DISCUSSION}

\section{1 - Plant height:}

As shown in Table (1) plants grown in peatmoss only gave $47.26 \mathrm{~cm}$ and $57.24 \mathrm{~cm}$ as best results as compared with peat: sand medium in first and second seasons, respectively. This increase was significantly in the second season. Similar results were obtained by Wazir et al. (2003) on Dracaena deremensis; El-Khateeb et al. (2006) on Ficus alii, Papafotiou et al. (2008) on Codiaeum variegatum and Salvador (2008) on Polypodium aureum,

NPK fertilizers and NPK fertilizers plus trace elements increased plant height compared with control in the first season, while in the second season; all treatments increased it compared to control, except NPK at 3 and $4 \mathrm{~g} / \mathrm{pot}$ treatments which decreased it. The best results were NPK at $1 \mathrm{~g} /$ plant and $\mathrm{NPK}+50 \mathrm{ppm}$ trace elements in the first and second seasons, respectively.

Interaction between soil media and chemical fertilizers had a significant effect on the plant height. NPK at $1 \mathrm{~g} /$ plant and peatmoss treatment gave the maximum increase in first and second seasons. Whereas the shortest plants were obtained from control and peat: sand treatment in the first season and from NPK at $4 \mathrm{~g} /$ plant combined with peat: sand in the second season.

\section{2-Stem diameter:}

The results in Table (1) showed that peat: sand growing media gave the best results compared to peatmoss medium in first and second seasons. These results are in agreement with those obtained by Stamps and Evans (1999) on Dracaena marginata; Wazir et al.(2004) on Schefflera actinophylla and ElKhateeb et al. (2006) on Ficus alii, they showed that using peatmoss in growing media increased stem diameter.

All fertilization treatments had no significant effect on stem diameter compared to control in the first season, except NPK at $1 \mathrm{~g}+50 \mathrm{ppm}$ trace elements which significantly increased it. This trend was different in the second season. NPK at 1 and $2 \mathrm{~g} /$ plant significantly increased stem diameter compared with control. While increasing NPK fertilization to 3 and $4 \mathrm{~g} /$ plant significantly decreased stem diameter compared with control. NPK at $1 \mathrm{~g}$ combined with trace elements at 50 or $100 \mathrm{ppm}$ significantly increased stem diameter compared with control treatment. The highest value was obtained due to NPK at $1 \mathrm{~g}+100 \mathrm{ppm}$ trace elements.

Interaction between growing media and chemical fertilization had a significant effect on stem diameter in both seasons. The highest value was obtained from the plants growing in peat: sand and treated with $1 \mathrm{~g} \mathrm{NPK}+50$ ppm trace elements in the first season and from plant fertilized by $1 \mathrm{~g} \mathrm{NPK}+100$ 
Table 1. Effect of soil media, NPK fertilizers and trace elements on plant height $(\mathrm{cm})$ and stem diameter $(\mathrm{cm})$ of Dracaena marginata "Bicolor" at 2006/2007 and 2007/2008 seasons.

\begin{tabular}{|c|c|c|c|c|c|c|c|}
\hline \multicolumn{2}{|c|}{ Fertilization } & \multicolumn{6}{|c|}{ Soil media (A) } \\
\hline \multirow{3}{*}{\multicolumn{2}{|c|}{ Treatments (B) }} & M 1 & M2 & Mean & M1 & M2 & Mean \\
\hline & & \multicolumn{3}{|c|}{$2006 / 2007$} & \multicolumn{3}{|c|}{$2007 / 2008$} \\
\hline & & \multicolumn{6}{|c|}{$\overline{\text { Plant height (cm) }}$} \\
\hline Control & & 45.67 & 38.50 & 42.08 & 54.17 & 57.33 & 55.75 \\
\hline \multirow[t]{4}{*}{ NPK at g/ pot } & 1 & 54.00 & 48.33 & 49.67 & 63.33 & 60.00 & 61.67 \\
\hline & 2 & 47.67 & 43.83 & 45.75 & 59.67 & 57.67 & 58.67 \\
\hline & 3 & 45.50 & 48.67 & 47.08 & 52.67 & 51.67 & 52.17 \\
\hline & 4 & 44.42 & 41.25 & 42.83 & 46.83 & 45.67 & 46.25 \\
\hline \multirow{2}{*}{$\begin{array}{l}\text { NPK1g + trace } \\
\text { elements }(\text { ppm })\end{array}$} & 50 & 49.17 & 48.67 & 48.92 & 61.67 & 62.17 & 61.92 \\
\hline & 100 & 47.42 & 45.67 & 46.54 & 62.33 & 57.33 & 59.83 \\
\hline \multicolumn{2}{|l|}{ Mean } & 47.26 & 46.01 & $\overline{-----}$ & 57.24 & 55.98 & ----- \\
\hline LSD at 0.05 for: & $\begin{array}{r}(\mathbf{A}) \\
(\mathbf{B}) \\
(\mathbf{A B}) \\
\end{array}$ & \multicolumn{4}{|c|}{$\begin{array}{r}\text { N.S. } \\
1.40 \\
1.908\end{array}$} & & $\begin{array}{l}1.04 \\
1.95 \\
2.75 \\
\end{array}$ \\
\hline \multirow{2}{*}{\multicolumn{2}{|c|}{ Control }} & \multicolumn{6}{|c|}{ Stem diameter $(\mathrm{cm})$} \\
\hline & & 1.21 & 1.32 & 1.26 & 1.26 & 1.42 & 1.34 \\
\hline \multirow[t]{4}{*}{ NPK at $1 \mathrm{~g} /$ pot } & 1 & 1.21 & 1.28 & 1.25 & 1.42 & 1.39 & 1.40 \\
\hline & 2 & 1.17 & 1.22 & 1.20 & 1.42 & 1.42 & 1.42 \\
\hline & 3 & 1.14 & 1.33 & 1.24 & 1.30 & 1.26 & 1.28 \\
\hline & 4 & 1.22 & 1.25 & 1.24 & 1.27 & 1.21 & 1.24 \\
\hline \multirow{2}{*}{$\begin{array}{l}\text { NPK 1g+ trace } \\
\text { elements ( ppm) }\end{array}$} & 50 & 1.27 & 1.37 & 1.32 & 1.35 & 1.46 & 1.41 \\
\hline & 100 & 1.18 & 1.33 & 1.25 & 1.50 & 1.46 & 1.48 \\
\hline \multicolumn{2}{|l|}{ Mean } & 1.20 & 1.30 & $\begin{array}{c}---- \\
\end{array}$ & 1.36 & 1.38 & $\begin{array}{ll}--- \\
\end{array}$ \\
\hline \multicolumn{8}{|c|}{ LSD at 0.05 for: } \\
\hline & (A) & & & 0.02 & & & 0.03 \\
\hline & (B) & & & 0.04 & & & 0.05 \\
\hline & $(\mathrm{AB})$ & & & 0.05 & & & 0.07 \\
\hline M1 = Peatmoss & \multicolumn{4}{|c|}{ M2 = Peat + sand (1:1 by volume $)$} & \multicolumn{3}{|c|}{ Trace elements $=\mathrm{Fe}+\mathrm{Mn}+\mathrm{Zn}$} \\
\hline $\begin{array}{l}\text { ppm trace elen } \\
\text { season. Wherea } \\
\text { peatmoss and tr } \\
\text { plant combined }\end{array}$ & $\begin{array}{l}\text { nents/ } \\
\text { as the } \\
\text { reated } \\
\text { with }\end{array}$ & $\begin{array}{l}\text { plant } \\
\text { least } \\
\text { with } 3 \\
\text { eat: san }\end{array}$ & $\begin{array}{l}\text { nd gro } \\
\text { alues } \\
\text { NPK/ } \\
\text { d (1:1) }\end{array}$ & $\begin{array}{l}\text { ing in } p \\
\text { re obtail } \\
\text { ant in th } \\
\text { the seco }\end{array}$ & $\begin{array}{l}\text { atmoss } \\
\text { ed fror } \\
\text { first se } \\
\text { d one. }\end{array}$ & $\begin{array}{l}\text { edium } \\
\text { he plar } \\
\text { on and }\end{array}$ & $\begin{array}{l}\text { he second } \\
\text { growing in } \\
4 \mathrm{~g} \mathrm{NPK}\end{array}$ \\
\hline
\end{tabular}




\section{3 - Number of leaves/plant:}

Data in Table (2) showed that plants grown in peatmoss medium gave the highest number of leaves/plant compared with peat + sand medium in first and second seasons. This increase was significant in the first season. Similar results were obtained by Wazir et al. (2004) on Schefflera actinophylla; El-Khateeb et al. (2006) on Ficus alii ; Papafotiou et al. (2008) on Codiaeum variegatum and Salvador (2008) on Polypodium aureum.

All fertilization treatments significantly increased number of leaves/plant compared with control plants, except $4 \mathrm{~g}$ NPK treatment which decreased it in the first season. On the other hand, all fertilization treatments decreased number of leaves/plant compared with control in the second season. The best result was obtained from $1 \mathrm{~g} \mathrm{NPK}+100 \mathrm{ppm}$ trace elements/plant and the lowest result was obtained from $4 \mathrm{~g} \mathrm{NPK/} \mathrm{plant} \mathrm{in} \mathrm{the} \mathrm{first} \mathrm{season.} \mathrm{In} \mathrm{the} \mathrm{second} \mathrm{season} \mathrm{best} \mathrm{result}$ was produced from control and the lowest result was obtained from $4 \mathrm{~g} \mathrm{NPK/}$ plant.

Interaction between soil media and chemical fertilization had a significant effect on the number of leaves/ plant. The highest value was obtained from $1 \mathrm{~g} \mathrm{NPK}+50 \mathrm{ppm}$ trace elements combined with peatmoss, while the lowest number of leaves/ plant was obtained from NPK at $4 \mathrm{~g} /$ plant combined with peat + sand in the first season. Whereas in the second season, control and peat+ sand gave the best result in the second season, while the lowest value was obtained from plants fertilized by $4 \mathrm{~g} \mathrm{NPK} /$ plant combined with peat + sand medium.

\section{4-Leaf area:}

The results presented in Table (2) showed that, peat: sand gave the highest leaf area as compared with peatmoss medium in the first season. Whereas soil media had no significant effect on leaf area in the second season. These results are in harmony with those obtained by Gad (2003) on Ficus benjamina, Singh and Nair (2003) stated that on some foliage plants and El-Khateeb et al., (2006) on Ficus alii.

Chemical fertilization treatments significantly increased leaf area compared with control plants in the first season. The best result was obtained from plants fertilized with NPK at $1 \mathrm{~g}$ combined with $50 \mathrm{ppm}$ trace elements. In the second season, NPK at $1 \mathrm{~g} /$ plant alone or combined with $50 \mathrm{ppm}$ trace elements significantly increased leaf area compared with control. While NPK treatments at 3 and $4 \mathrm{~g} /$ plant significantly decreased leaf area as compared with control.

Interaction between growing media and chemical fertilization had a significant effect on leaf area in both seasons. Plants grown in peat + sand and fertilized with NPK at $1 \mathrm{~g}+50 \mathrm{ppm}$ trace elements gave the highest leaf area 
Table 2. Effect of soil media, NPK fertilizers and trace elements on number of leaves/ plant and leaf area $\left(\mathrm{cm}^{2}\right)$ of Dracaena marginata "Bicolor" at 2006/2007 and 2007/2008 seasons.

\begin{tabular}{|c|c|c|c|c|c|c|c|}
\hline \multirow{3}{*}{\multicolumn{2}{|c|}{$\begin{array}{l}\text { Fertilization } \\
\text { Treatments (B) }\end{array}$}} & \multicolumn{6}{|c|}{ Soil media } \\
\hline & & M 1 & M2 & Mean & M1 & M2 & Mean \\
\hline & & \multicolumn{3}{|c|}{$2006 / 2007$} & \multicolumn{3}{|c|}{$2007 / 2008$} \\
\hline \multirow{2}{*}{\multicolumn{2}{|c|}{ Control }} & \multicolumn{6}{|c|}{ Number of leaves/plant } \\
\hline & & 39.17 & 47.50 & 43.33 & 49.17 & 59.00 & 54.08 \\
\hline NPK at & $\mathbf{1}$ & 50.17 & 44.67 & 47.42 & 52.67 & 50.17 & 51.42 \\
\hline 1g/ pot & 2 & 49.67 & 43.17 & 46.42 & 47.67 & 48.00 & 47.83 \\
\hline \multirow{4}{*}{$\begin{array}{l}\text { NPK 1g+ trace } \\
\text { elements (pm) }\end{array}$} & 3 & 49.17 & 44.00 & 46.58 & 46.33 & 43.17 & 44.75 \\
\hline & 4 & 40.67 & 30.50 & 35.58 & 44.00 & 35.00 & 39.50 \\
\hline & 50 & 53.33 & 39.50 & 46.42 & 46.83 & 54.83 & 50.83 \\
\hline & 100 & 44.00 & 51.67 & 47.83 & 55.33 & 51.33 & 53.33 \\
\hline \multicolumn{2}{|l|}{ Mean } & 46.60 & 43.00 & ---- & 48.86 & 48.79 & $-\cdots$ \\
\hline \multirow[t]{3}{*}{ LSD at 0.05 for: } & (A) & \multicolumn{5}{|c|}{1.20} & N.S. \\
\hline & (B) & \multicolumn{5}{|c|}{2.66} & 1.94 \\
\hline & $(\mathbf{A B})$ & \multicolumn{5}{|c|}{3.76} & 2.74 \\
\hline \multirow{6}{*}{$\begin{array}{l}\text { Control } \\
\text { NPK at 1g/ } \\
\text { pot }\end{array}$} & & \multicolumn{6}{|c|}{ Leaf area $\left(\mathrm{cm}^{2}\right)$} \\
\hline & & 55.65 & 76.13 & 65.89 & 103.00 & 89.12 & 96.04 \\
\hline & $\mathbf{1}$ & 79.01 & 84.48 & 81.75 & 100.70 & 102.00 & 101.30 \\
\hline & 2 & 84.56 & 72.71 & 78.64 & 97.67 & 95.06 & 96.37 \\
\hline & 3 & 69.28 & 75.14 & 72.21 & 85.03 & 89.88 & 87.46 \\
\hline & 4 & 73.26 & 69.65 & 71.45 & 71.81 & 72.55 & 72.18 \\
\hline \multirow{2}{*}{$\begin{array}{l}\text { NPK 1g+ trace } \\
\text { elements (ppm }\end{array}$} & $\mathbf{5 0}$ & 87.04 & 91.27 & 89.16 & 101.80 & 103.80 & 102.80 \\
\hline & 100 & 74.12 & 84.55 & 79.33 & 88.25 & 95.57 & 91.91 \\
\hline \multicolumn{2}{|l|}{ Mean } & 74.70 & 79.13 & ---- & 92.61 & 92.57 & ---- \\
\hline \multirow[t]{3}{*}{ LSD at 0.05 for: } & (A) & & & 2.00 & & & N.S. \\
\hline & (B) & & & 3.75 & & & 4.13 \\
\hline & (AB) & & & 5.30 & & & 5.83 \\
\hline
\end{tabular}

in the first season. The lowest values were obtained from the plants growing in peatmoss and untreated (control) in the first season and from $4 \mathrm{~g} \mathrm{NPK} /$ plant and peatmoss medium in the second season.

\section{5-Fresh weight of leaves:}

As shown in Table (3) plants grown in peat + sand significantly gave the heaviest fresh weight of leaves/ plant compared with plants grown in peatmoss in the first season. Whereas in the second season, growing plants in peatmoss 
medium significantly produced the heaviest fresh weight of leaves/ plant compared with peat + sand medium. Similar results are obtained by ,Wazir et al. (2003) on Dracaena deremensis; El-Khateeb et al. (2006) on Ficus alii; Papafotiou et al. (2008) on Codiaeum variegatum and Salvador (2008) on Polypodium aureum.

All fertilization treatments significantly increased fresh weight of leaves/ plant compared with control plants, except NPK at $4 \mathrm{~g} /$ plant which significantly decreased it in the first season. On the other hand, all fertilization treatments decreased fresh weight of leaves compared with control, except $1 \mathrm{~g} \mathrm{NPK}$ at $1 \mathrm{~g}$ alone or combined with $50 \mathrm{ppm}$ trace elements which gave the heaviest fresh weight of leaves/ plant in the second season.

Interaction between growing media and chemical fertilization significantly affected fresh weight of leaves/ plant. NPK at $1 \mathrm{~g} /$ plant combined with peat + sand, and NPK at $1 \mathrm{~g} /$ plant combined with peatmoss gave the best results in the first and second seasons, respectively. Whereas the lowest results were obtained from control and peatmoss treatment in the first season and from 4 $\mathrm{g} \mathrm{NPK}$ at $4 \mathrm{~g} /$ plant combined with peat+ sand in the second one.

\section{6- Dry weight of leaves:}

The data in Table (3) showed that peatmoss medium gave the best results in the first and second seasons as compared with peat + sand medium. This increase was significant in the first season. Similar results are obtained by Wazir et al. (2003) on Dracaena deremensis; El-Khateeb et al. (2006) on Ficus alii; Papafotiou et al. (2008) on Codiaeum variegatum; Salvador (2008) on Polypodium aureum.

All fertilization treatments significantly increased dry weight of leaves compared with control plants, except $4 \mathrm{~g}$ NPK treatment which significantly decreased it in the first season. On the other hand, all fertilization treatments decreased the dry weight of leaves compared with control, except $1 \mathrm{~g}$ NPK alone or combined with $100 \mathrm{ppm}$ trace elements which significantly increased it in the second season. The best results were obtained due to NPK at $1 \mathrm{~g} /$ plant in the first and second seasons. In contrast, the lowest values were obtained due to NPK at 4 $\mathrm{g} /$ plant in the first and second seasons. The stimulation effects of NPK on vegetative growth of many plants were studied by many authors; similar results are obtained by Wazir et al. (2004) on Schefflera actinophylla; Dorgham (2005) on Dieffenbachia plants; Jimenez and Lao (2005) on Dieffenbachia amoena cv. Tropic Snow; Segura et al. (2005) on Dieffenbachia maculata cv. Camille. 


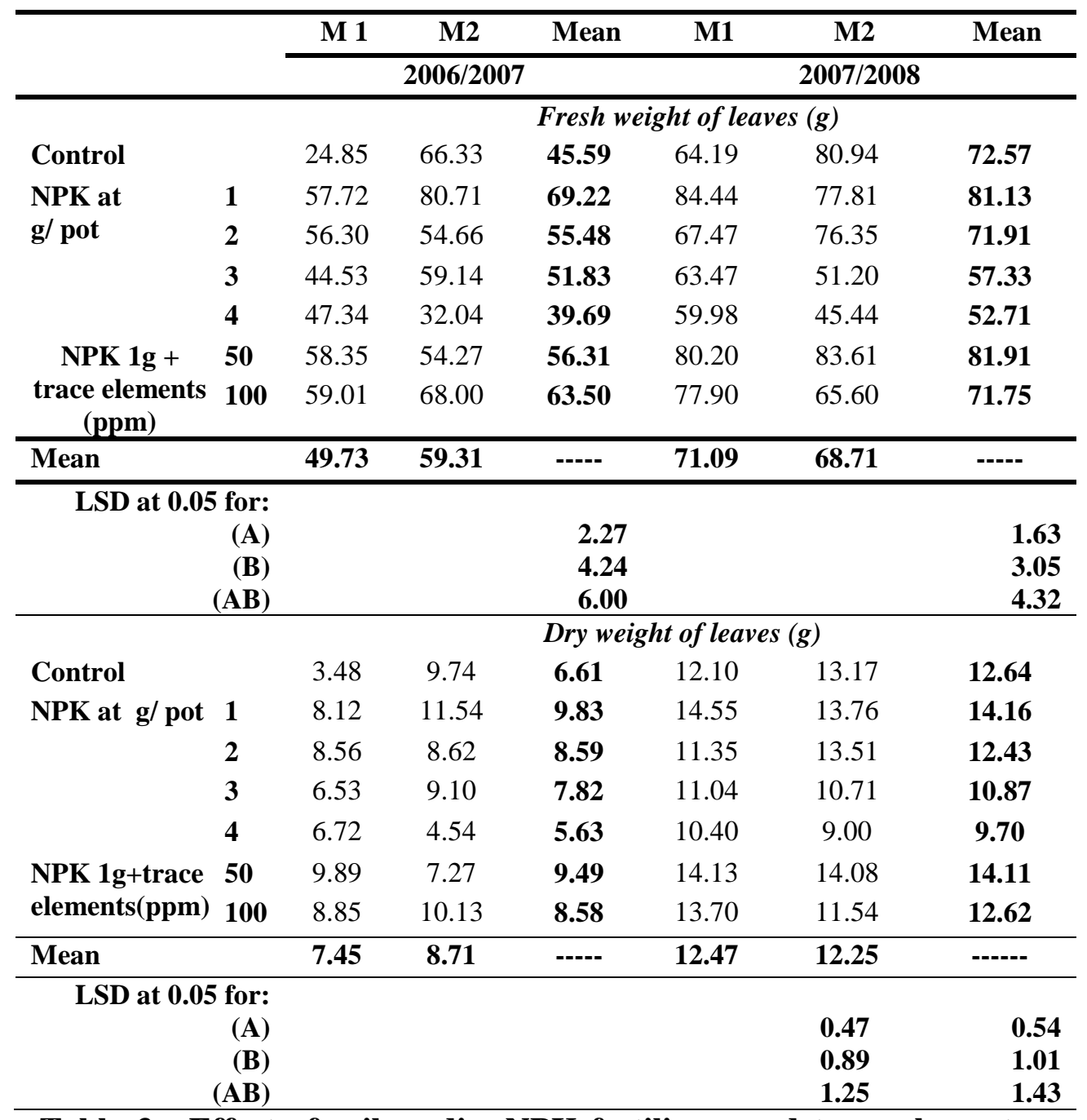

Table 3. Effect of soil media, NPK fertilizers and trace elements on fresh and dry weights of leaves (g/ plant) of Dracaena marginata "Bicolor" at 2006/2007 and 2007/2008 seasons.

M1 = Peatmoss $\quad$ M2 = Peat + sand (1:1 by volume $) \quad$ Trace elements $=\mathrm{Fe}+\mathrm{Mn}+\mathrm{Zn}$

Interaction between growing media and fertilizers had a significant effect on dry weight of leaves/plant in both seasons. The heaviest dry weight of leaves were obtained from the plants growing in peat+ sand and treated with 1 gm NPK/ plant in the first season, while in the second season the heaviest leaves dry weights were obtained due to growing plants in peatmoss and fertilized with $\mathrm{NPK}$ at $1 \mathrm{~g} /$ plant. Whereas the lowest values were obtained from the plants 
growing in peatmoss combined with unfertilized control in the first season, and from peat+ sand combined with NPK at $4 \mathrm{~g} /$ plant and in the second season.

\section{Total carbohydrates contents in leaves:}

As shown in Table (4) plants grown in peatmoss gave the highest total carbohydrates contents when compared with peat: sand medium in the first and second seasons. These results are in harmony with those obtained by Saleh (2000) on Ficus benjamina " Starlight" grew plants in different planting media, and indicated that peatmoss + sand + clay mixture resulted in higher total content of carbohydrates. El-Khateeb et al. (2006) on Ficus alii, found that using the mixtures of (clay+ peatmoss +perlite).and (clay+ sand+ vermiculite) increased the total carbohydrates in the different parts.

All chemical fertilization treatments increased total carbohydrates contents in the leaves compared with control plants, except NPK at 3 and $4 \mathrm{~g} /$ plant which decreased it in the first and second seasons. The best results were obtained from plants treated with NPK at $1 \mathrm{~g}+100 \mathrm{ppm}$ trace elements in the first and second seasons.

Concerning the interaction between soil media and chemical fertilizers, plants grown in peatmoss and treated with NPK at $1 \mathrm{~g}+100 \mathrm{ppm}$ trace elements gave the highest total carbohydrates contents in the first and second seasons. Whereas the lowest results were obtained from plants growing in peat + sand and treated with NPK at $4 \mathrm{~g}$ in the first season, and peatmoss combined with NPK at $4 \mathrm{~g} /$ plant in the second one.

\section{Elements percent:}

\section{- Nitrogen percent in leaves:}

The results presented in Table (4) showed that peatmoss medium gave the highest $\mathrm{N}$ percentages compared with peat + sand medium in the first and second seasons.

Chemical fertilization treatments at 1 and $2 \mathrm{~g} /$ plant increased nitrogen percent compared with control plants. Whereas NPK at 3 and $4 \mathrm{~g} /$ plant treatments decreased nitrogen percent as compared with control in the first and second seasons. NPK at $1 \mathrm{~g}+100 \mathrm{ppm}$ trace elements was the best treatment which gave the highest values in the first and second seasons. In contrast, the lowest values were obtained from plants fertilized with NPK at $4 \mathrm{~g} /$ plant in the first and second seasons.

Interaction between growing media and chemical fertilization showed that, the highest nitrogen percent were obtained from plants grown in peatmoss and fertilized with NPK at $1 \mathrm{~g}+100 \mathrm{ppm}$ trace elements in the first and second 
Table 4. Effect of soil media, NPK fertilizers and trace elements on total carbohydrates and nitrogen $(\%)$ in leaves of Dracaena marginata "Bicolor" at 2006/ 2007 and 2007/ 2008 seasons.

\begin{tabular}{|c|c|c|c|c|c|c|c|}
\hline \multirow{3}{*}{\multicolumn{2}{|c|}{$\begin{array}{l}\text { Fertilization } \\
\qquad \begin{array}{l}\text { Treatments (B) }\end{array}\end{array}$}} & \multicolumn{6}{|c|}{ Soil media } \\
\hline & & M 1 & M2 & Mean & M1 & M2 & Mean \\
\hline & & \multicolumn{3}{|c|}{$2006 / 2007$} & \multicolumn{3}{|c|}{$2007 / 2008$} \\
\hline & & \multicolumn{6}{|c|}{ Total carbohydrates (\%) } \\
\hline \multirow{5}{*}{$\begin{array}{l}\text { Control } \\
\text { NPK at g/ pot }\end{array}$} & & 33.82 & 32.41 & 33.12 & 31.72 & 30.50 & 31.11 \\
\hline & 1 & 35.39 & 34.24 & 34.82 & 39.23 & 35.47 & 37.35 \\
\hline & 2 & 34.32 & 33.36 & 33.84 & 31.73 & 34.14 & 32.94 \\
\hline & 3 & 29.38 & 28.81 & 29.09 & 29.58 & 30.13 & 29.86 \\
\hline & 4 & 28.73 & 27.42 & 28.08 & 27.67 & 28.56 & 28.12 \\
\hline \multirow{2}{*}{$\begin{array}{l}\text { NPK 1g + trace } \\
\text { elements (ppm) }\end{array}$} & 50 & 36.12 & 35.24 & 35.68 & 39.59 & 37.56 & 38.58 \\
\hline & 100 & 38.81 & 37.59 & 38.20 & 42.26 & 40.56 & 41.41 \\
\hline \multicolumn{2}{|l|}{ Mean } & 33.79 & 32.72 & $-\cdots$ & 34.54 & 33.85 & $-\cdots$ \\
\hline \multirow{6}{*}{$\begin{array}{l}\text { Control } \\
\text { NPK at g/ pot }\end{array}$} & & \multicolumn{6}{|c|}{ Nitrogen (\%) } \\
\hline & & 1.512 & 1.453 & 1.483 & 1.589 & 1.524 & 1.557 \\
\hline & 1 & 1.700 & 1.672 & 1.686 & 2.457 & 2.316 & 2.387 \\
\hline & 2 & 1.659 & 1.502 & 1.581 & 2.214 & 2.197 & 2.206 \\
\hline & 3 & 1.351 & 1.268 & 1.310 & 1.483 & 1.352 & 1.418 \\
\hline & 4 & 1.163 & 1.195 & 1.179 & 1.168 & 1.095 & 1.132 \\
\hline \multirow{2}{*}{$\begin{array}{l}\text { NPK 1g + trace } \\
\text { elements (ppm) }\end{array}$} & 50 & 1.718 & 1.695 & 1.707 & 2.620 & 2.605 & 2.156 \\
\hline & 100 & 1.826 & 1.807 & 1.817 & 2.850 & 2.730 & 2.790 \\
\hline \multicolumn{2}{|l|}{ Mean } & 1.561 & 1.513 & $-\cdots$ & 2.054 & 1.974 & $-\cdots$ \\
\hline M1 = Peatmoss & \multicolumn{4}{|c|}{$\mathrm{M} 2=$ Peat + sand (1:1 by volume $)$} & \multicolumn{3}{|c|}{ Trace elements $=\mathrm{Fe}+\mathrm{Mn}+\mathrm{Zn}$} \\
\hline
\end{tabular}

\section{-Phosphorus percent in leaves:}

As shown in Table (5) plants grown in peat + sand gave the highest phosphorus percent in the first and second seasons as compared with peatmoss medium.

All fertilization treatments increased phosphorus percent in the leaves compared with control plants in the first and second seasons, except $4 \mathrm{~g}$ NPK treatment which decreased it in the second season. The best result was obtained 
from $1 \mathrm{~g} \mathrm{NPK}+100 \mathrm{ppm}$ trace elements and NPK at $1 \mathrm{~g}+50 \mathrm{ppm}$ trace elements in the first and second seasons, respectively.

Interaction between growing media and chemical fertilization showed that, peat+ sand medium combined with NPK at $1 \mathrm{~g}+100 \mathrm{ppm}$ trace elements was the best treatment in the first and second seasons. Whereas the lowest results were obtained from plants grown in peat: sand medium and treated with NPK at $4 \mathrm{~g} /$ plant in both seasons.

\section{- Potassium percent in leaves}

The data in Table (5) showed that peatmoss medium gave the highest $\mathrm{K}$ contents in the first and second seasons as compared with peat + sand medium.

Chemical fertilization treatments increased potassium contents in the leaves compared with control plants in the first season, except NPK at $4 \mathrm{~g}$ treatment which decreased it. In the second season, all the treatments increased potassium contents compared to control, except NPK at $2 \mathrm{~g}$ and NPK at $1 \mathrm{~g}+100$ ppm trace elements treatments which decreased it.

Interaction between growing media and chemical fertilization showed that, the highest potassium contents were obtained from plants grown in peatmoss and treated with NPK at $1 \mathrm{~g}$ alone or combined with $50 \mathrm{ppm}$ trace elements in the first and second seasons, respectively. Whereas the lowest values were obtained from plants growing in peat+ sand and treated with NPK at $4 \mathrm{~g}$ /plant and NPK $1 \mathrm{~g}+50 \mathrm{ppm}$ trace elements in the first and second seasons, respectively.

\section{- Iron percent in leaves:}

The data presented in Table (6) showed that, plants growing in peatmoss had the highest Fe percent as compared with peat+ sand medium which gave the lowest values in the first and second seasons.

All fertilization treatments increased iron contents in leaves compared with control plants, except 4 gm NPK treatment which decreased it in the first and second seasons. The best result was obtained from $1 \mathrm{~g} \mathrm{NPK}+100 \mathrm{ppm}$ trace elements, while the lowest value was obtained from $4 \mathrm{~g}$ NPK/ plant in both seasons.

Interaction between growing media and chemical fertilization showed that peatmoss medium combined with $1 \mathrm{~g}$ NPK $+100 \mathrm{ppm}$ trace elements gave the highest $\mathrm{Fe}$ contents in leaves in the first and second seasons. Whereas the lowest values were obtained from plants grown in peat + sand and fertilized with NPK at $4 \mathrm{~g} /$ plant in first and second seasons. 
Table 5. Effect of soil media, NPK fertilizers and trace elements on phosphorus and potassium $(\%)$ in the leaves of Dracaena marginata "Bicolor" at 2006/2007 and 2007/2008 seasons.

\begin{tabular}{|c|c|c|c|c|c|c|c|}
\hline \multirow{3}{*}{\multicolumn{2}{|c|}{$\begin{array}{l}\text { Fertilization } \\
\text { Treatments (B) }\end{array}$}} & \multicolumn{6}{|c|}{ Soil media } \\
\hline & & M1 & M2 & Mean & M1 & M2 & Mean \\
\hline & & \multicolumn{3}{|c|}{$2006 / 2007$} & \multicolumn{3}{|c|}{$2007 / 2008$} \\
\hline & \multicolumn{6}{|c|}{ Phosphorus (\%) } \\
\hline & & 0.129 & 0.120 & 0.125 & 0.152 & 0.145 & 0.149 \\
\hline \multirow{4}{*}{$\begin{array}{l}\text { NPK at } \\
\text { g/ pot }\end{array}$} & 1 & 0.181 & 0.176 & 0.179 & 0.270 & 0.265 & 0.268 \\
\hline & 2 & 0.263 & 0.259 & 0.261 & 0.315 & 0.390 & 0.353 \\
\hline & 3 & 0.149 & 0.138 & 0.144 & 0.270 & 0.281 & 0.276 \\
\hline & 4 & 0.530 & 0.089 & 0.309 & 0.142 & 0.136 & 0.139 \\
\hline \multirow{2}{*}{$\begin{array}{l}\text { NPK1g+ trace } \\
\text { elements(ppm) }\end{array}$} & 50 & 0.135 & 0.129 & 0.132 & 0.411 & 0.405 & 0.408 \\
\hline & 100 & 0.163 & 1.179 & 0.671 & 0.323 & 0.449 & 0.386 \\
\hline \multicolumn{2}{|l|}{ Mean } & 0.221 & 0.299 & $-\cdots$ & 0.269 & 0.296 & $-\cdots-$ \\
\hline \multirow{6}{*}{$\begin{array}{l}\text { Control } \\
\text { NPK at } \\
\text { g/ pot }\end{array}$} & & \multicolumn{6}{|c|}{ Potassium (\%) } \\
\hline & & 0.575 & 0.565 & 0.570 & 1.470 & 1.356 & 1.413 \\
\hline & 1 & 1.125 & 1.106 & 1.116 & 2.020 & 1.930 & 1.975 \\
\hline & 2 & 0.950 & 0.757 & 0.854 & 2.400 & 0.220 & 1.310 \\
\hline & 3 & 0.847 & 0.820 & 0.834 & 2.450 & 2.310 & 2.380 \\
\hline & 4 & 0.564 & 0.469 & 0.517 & 1.720 & 1.640 & 1.680 \\
\hline \multirow{2}{*}{$\begin{array}{l}\text { NPK g+ trace } \\
\text { elements (ppm) }\end{array}$} & 50 & 0.717 & 0.657 & 0.687 & 2.750 & 2.569 & 2.659 \\
\hline & 100 & 0.762 & 0.720 & 0.741 & 1.940 & 0.210 & 1.075 \\
\hline \multicolumn{2}{|l|}{ Mean } & 0.791 & 0.728 & --- & 2.107 & 1.462 & $\overline{----}$ \\
\hline
\end{tabular}

As shown in Table (6) plants grown in peatmoss medium gave the highest $\mathrm{Mn}$ percent in leaves as compared with peat+ sand medium which gave the lowest values in first and second seasons.

All fertilization treatments increased manganese percent in leaves as compared with control plants, except NPK at $4 \mathrm{~g}$ treatment which decreased it in the first and second seasons. The best result was obtained from NPK at $1 \mathrm{~g}+100$ ppm trace elements, while the lowest value was obtained from plants treated with NPK at $4 \mathrm{~g} /$ plant in the first and second seasons.

Interaction between peatmoss growing media and NPK at $1 \mathrm{~g}+100 \mathrm{ppm}$ trace elements gave the highest Mn contents in leaves in the first and second 
Table 6. Effect of soil media, NPK fertilizers and trace elements on iron, manganese and zinc \% (ppm) in the leaves of Dracaena marginata "Bicolor" at 2006/2007 and 2007/2008 seasons.

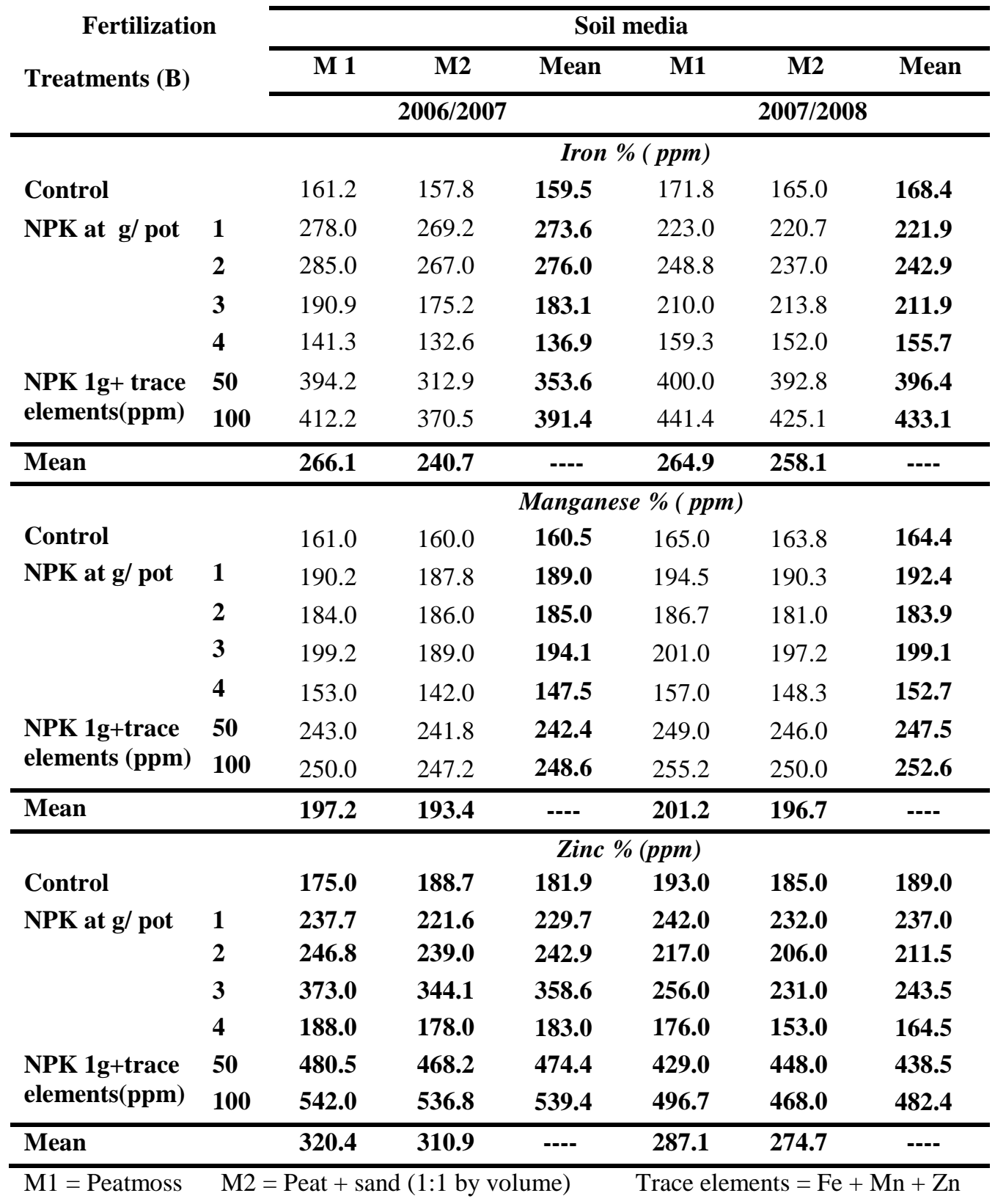


seasons. Whereas the lowest results were obtained from plants grown in peat + sand and treated with NPK at $4 \mathrm{gm} /$ plant in the first and second seasons.

\section{-Zinc percent in leaves:}

The results presented in Table (6) showed that, peatmoss medium gave the highest zinc percent in leaves as compared with peat+ sand medium in the first and second seasons. Some authors declared the importance of potting substrates in increasing the availability of nutrient elements and enhancing their absorption by plant such as Saleh (2000) on Ficus benjamina "Starlight" grew plants in different planting media, and indicated that peatmoss + sand + clay mixture resulted in higher N, P and K in the leaves. Gad (2003) on Ficus benjamina found that the peatmoss alone and its mixture with clay or vermiculite $(1: 1 \mathrm{v} / \mathrm{v})$ significantly increased $\mathrm{N}, \mathrm{P}$ and $\mathrm{K}$ percent in the leaves.

Chemical fertilization treatments increased zinc contents in leaves as compared with control plants in the first season, while in the second season; all the treatments increased it compared to control, except NPK at $4 \mathrm{~g}$ treatment which decreased it. The best results were obtained from $1 \mathrm{~g} \mathrm{NPK}+100 \mathrm{ppm}$ trace elements in the first and second seasons. In contrast, the lowest values were obtained from control and NPK at $4 \mathrm{~g}$ in the first and second seasons, respectively. Similar results were obtained by Dorgham (2005) on Dieffenbachia and Philodendron plants; Srinivasa (2006) on Anthurium andraeanum, they showed that NPK fertilization significantly affected N, P, K, Ca and Mg contents.

Concerning the interaction between growing media and chemical fertilization the data showed that, peatmoss medium combined with NPK at $1 \mathrm{~g}$ +100 ppm trace elements gave the best results in the first and second seasons. Whereas the lowest values were obtained from control plants growing in peatmoss in the first season, and plants growing in peat + sand and treated with 4 $\mathrm{g} \mathrm{NPK/} \mathrm{plant} \mathrm{in} \mathrm{the} \mathrm{second} \mathrm{season.}$

\section{Recommendation:}

To obtain the best results on vegetative growth, and chemical composition of Dracaena marginata plants, we recommended the use of peatmoss or peat + sand media and fertilized with NPK at $1 \mathrm{~g}$ alone or combined with trace elements (Fe, Mn and $\mathrm{Zn}$ ) at 50 or 100 ppm monthly.

\section{REFERENCES}

Dorgham, A. H. (2005). Physiological studies on Dieffenbachia, Philodendron and Syngonium plants. M. Sc. Thesis, Faculty of Agriculture, Cairo University, Egypt. 
EL-Khateeb, M. A, EL-Maadawy, E. E and EL-Atter, A. A.(2006). Effect of growing media on growth and chemical composition of Ficus alii plants. Annals of Agricultural Science, Moshtohor, 46 (2) :1987-1998.

Gad, M.M. (2003). Evaluation of various potting media and fertilization levels for commercial nursery production of Ficus benjamina, L. Assuit Journal of Agriculture Science, 34 (4): 123-150.

Herbert, D.; Philips, P. J. And Strange, R. E. (1971). Determination of Total Carbohydrates. Methods in Microbiology, 5B:, 210-344.

Huxley, A. (1992). The New Royal Horticultural Society Dictionary of Gardening. Vol. 3 (L-Q). The Stotkton Press, N.Y., USA.

Isaac, R. and Kerber, J. (1971). Techniques and uses in soil, plant and water analysis. In: Atomic Absorption and Photometry. Madison, Wisconsin, 1971, p. 17-37.

Jimenez, S and Lao, M. T. (2005). Influence of nitrogen form on the quality of Dieffenbachia amoena "Tropic Snow". HortScience, 40 (2):386- 390.

Li, Y.C. and Zhang, M. (2002). Effects of urea and nitric acid on water and medium quality on response of Anthurium. Hort. Technology, 12 (1):131134

Papafotiou, M; Avajianneli, B; Michos, C; Chatzipavlidis, I. and Liakouraanthocyanin, V. (2008). Anthocyanin concentration of croton (Codiaeum variegatum) leaves as affected by cotton gin trash compost. Acta Horticulturae, 779: 355-360.

Piper C. S. (1950). Soil and plant analysis. The University of Adelaide, Australia. 258-275.

Poole, R. T. and Conover, C. A. (1992). Fertilizer levels and medium affect foliage plant growth in an EBB and flow irrigation system. Journal of Environmental Horticulture, 10 (2): 81-86.(Hort. Abst., 63: 2134).

Pregl, P. (1945). Quantitativa organic microanalysis. $4^{\text {th }}$ ed. Churchill London.

Said, R. M. (1997).Effect of some chemical fertilization on croton plant. M. Sc. Thesis,. Faculty of Agriculture, Cairo University, Egypt.

Saleh, S. I. (2000). Effect of different planting media on the growth and chemical composition of Ficus benjamina "Starlight" plants grown under two locations "outdoor and plastic house" conditions. Egyptian Journal. Hort., 27 (4): 543-568.

Salvador, E. D. (2008). Evaluation of alternative substrates to the xaxim dust for 'matogrossense' fern (Polypodium aureum) cultivation. Ishs Acta Horticulture, 779: 547-554. 
Segura, M. L.; Rodriguez, J. M.; Jimenez, S. and Lopez, J.; Carrasco, I. (2005). Dieffenbachia growth responses and $\mathrm{N}$ leaching from containergrown plants fertilized by several methods. Acta Horticulture, 697: 387391.

Singh, D. R. and Nair, S. A. (2003). Standardization of rooting media for cuttings of certain house plants. Journal. Ornamental Hort. New-Series, 6 (1): 78-79.

Snedecor, G.W. and Cochran, W.G. (1980). Statistical Methods. $\left(7^{\text {th }}\right.$ Ed.) Iowa state, University Press, Ames Iowa U.S.A. P. 953.

Srinivasa, V. (2006). Effect of fertilizers on leaf nutrient content in Anthurium cv. Chaco. Crop Research Hisar, 31 (1): 78-80.

Troug, E. and Meyer, A. (1939). Improvement in the denies colorimetric method for phosphorus and arsenic. Ind. Eng. Chem. Anal., Ed.1:136139.

Wazir, M. G.; Amin, N. U.; Ishtiaq, M.; and Khan, I. (2003). Effects of different soil media on the growth of Dracaena deremensis var. Janet Craige cuttings. Sarhad Journal of Agriculture, 19 (1): 31-34.

Wazir, M. G.; Noorul-Amin; Imtiaz-Khan and Khan, M. I. (2004). Effects of different potting mixtures and nitrogen sources on the performance of Brassaia seedlings. Sarhad Journal of Agriculture, 20 (1): 25-31. 


\section{تأثير بيئات النمو والتسميد الكيماوي علي النمو والتركيب الكيماوي لنبات

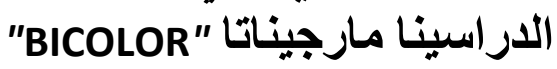

عبد الفقور عوض السيد ـ أحمد سلامه الليثي ـ شيماء محمود أمين عثمان حيلر قسم بساتين الزينةـ كلية الزر اعة- جامعة القاهزة - -ج.م.ع.

اجري هذا البحث بمزرعة قسم الزينة ـ كلية الزراعة - جامعة القاهرة خلال

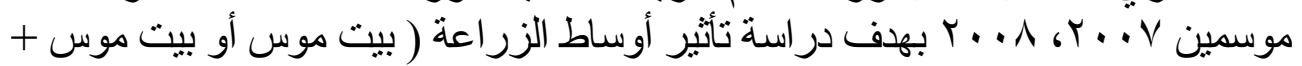

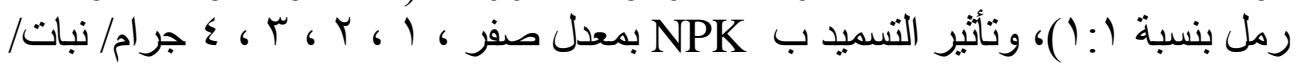

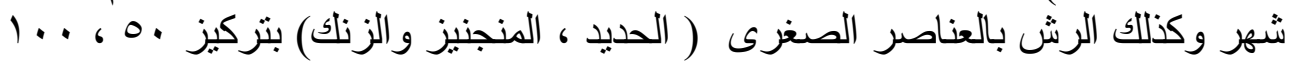

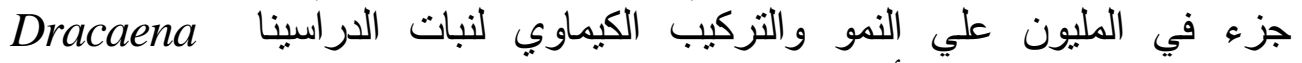
marginata 'Bicolor' أدي استخدام البيت موس كبيئة للزراعة إلي الحصول التصول علي أعلي القيم من حيث

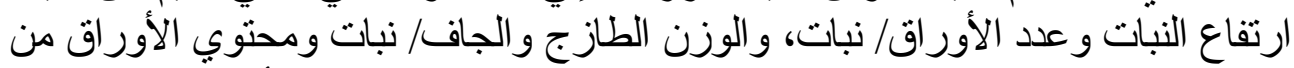

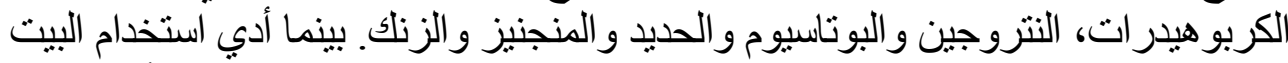

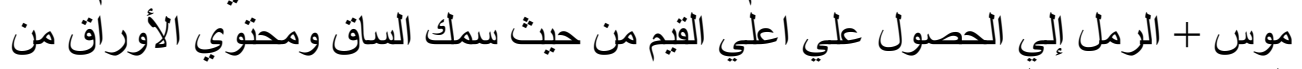

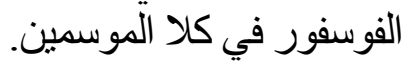

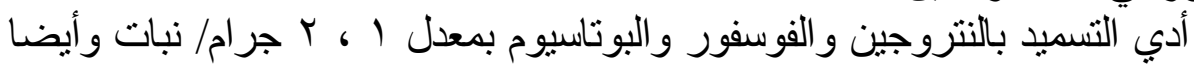

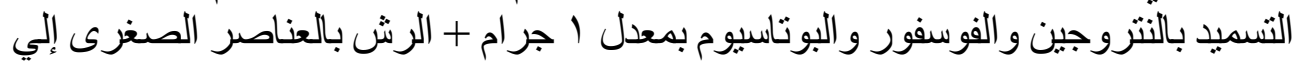

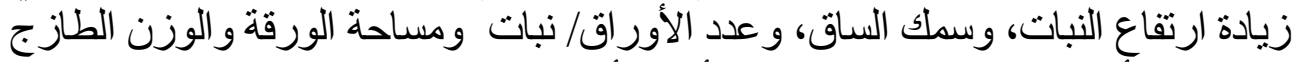

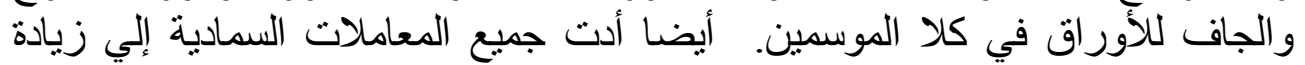

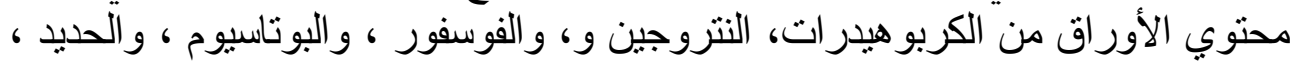

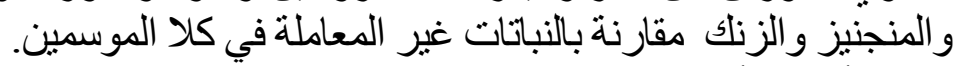

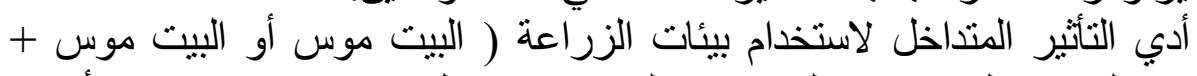

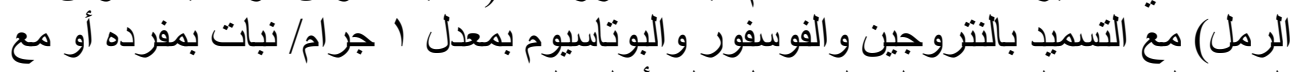
الرش بالعناصر الصغرى إلي الحصول علي أعلي القيم. 